\title{
THE INFLUENCE OF GENDER ON READING COMPREHENSION
}

\author{
Gabriela Ngongare, Nurmin Samola Aloysius Rettob \\ Jurusan Pendidikan Bahasa Inggris, Fakultas Bahasa dan Seni Universitas Negeri Manado \\ gngongare@gmail.com
}

\begin{abstract}
Abstrak: This study deals with the effect of gender differences on reading comprehension. The purpose is to answer the question: Does female students perform more significantly on reading comprehension of neutral text than do male students? The study that was conducted in the academic year 2019/2020, is pre-experimental in nature intact group design, and involved 60 grade students purposely selected based on their gender as the sample. They are then assigned into two treatment groups. The data are collected using an objective type test in multiple-choice format, and are analyzed statistically using t-test for independent sample. Result of the analysis showed that at $p .05$ and $d f 58$, the $\mathrm{t}$-observed is larger than $\mathrm{t}_{\text {-table }}[3.333 \geq 2.000)$. This indicates that female students outperformed their male counterparts in reading comprehension. In other words, it can be stated that gender differences affect reading comprehension.
\end{abstract}

Keywords: gender, reading comprehension, neutral text, EFL 


\section{INTRODUCTION}

It has been widely admitted that reading is an important language skill that should be nurtured from the early life of a child. It is related to the language exposure that one experiences. In English language learning context, if one reads a lot. he may develop not only his knowledge of the language but also its use. Reading in English surely contributes pivotal task in the vocabulary gain and the knowledge of grammar. Pietil and Merikivi (2014: 20) state, "Reading undoubtedly influences vocabulary knowledge and growth." By reading, one could pick up words and phrases and use them in listening, speaking or writing. Therefore, reading is an effective way to develop our communicative competence in English.

Reading comprehension depends on the dynamic interaction among: (1) the reader's background knowledge, and (2) the information in the text being read. That is why, it is said that the more linguistic and content schemata one has, the easier he/she understands and decodes what is being read (UK Essays, 2017).

According to schema theory, a text does not carry meaning itself, but provides directions to readers about the retrieval of relevant information from prior knowledge (Carrell\&Eisterhold, 1983). This means that successful comprehension depends mainly on students' ability to activate his/her background knowledge and his/her language knowledge. That is why Stanovich (1980) considers reading as an interactive compensatory process. It is compensatory in that the reader relies on his/her background knowledge when he/she finds it is difficult to understand linguistic information. Conversely, he/she relies on the text when he/she finds it is difficult to activate related background knowledge.
Comprehension is also affected by, for example, gender. Saidi and AlMahrooqi(2012) claims genders influence on education, especially on foreign language learning, cannot be denied. Doolittle and Welsch (1989) find out that females scored higher than males on humanities-oriented readings whereas males did better than females on passages with science-oriented topics. Shahmohammad (2011) finds that males will have greater comprehension achievement if they read the texts, which sound masculine, and females will have greater comprehension achievement provided that they read texts, which are about feminine topics. Lietz, Petra (2006) revealed girls' superiority over boys in reading achievement.

The other PISA study was carried out in 2006, and again, in all countries, "females obtained higher average scores over males. A world-wide measurement of reading ability was conducted, also by the PIRLS in 35 countries" (Mullis, Martin, Gonzalez, \& Kennedy, 2003). In that study, "the reading-test scores of the females in all the countries are significantly higher than the males."

Not all studies reveal that gender has significant effects on comprehension. Vlachos and Papadimitriou (2015), for example, finds that gender does not play an important role in reading performance. Lietz, Petra (2006) also reveal that there was little or no evidence of gender differences. As with Lietz, Salehi et al., (2014) find that gender does not have any significant effect on text comprehension. Similarly, Yazdanpanah (2007) shows that the overall performance of males and females on the reading test was not significantly different. Therefore, more studies are needed to verify the claim that females' superiority in reading 
comprehension over males (Lynn and Mikk, 2009) should be verified.

\section{RESARCH METHODOLOGY}

The purpose of this study is to describe the effect of gender on students reading comprehension. In terms of purpose, this study is experimental in nature, in that, it aims at describing a causeeffect relationship between gender (male vs. female) and reading comprehension of neutral texts. The relationship can be displayed as this:

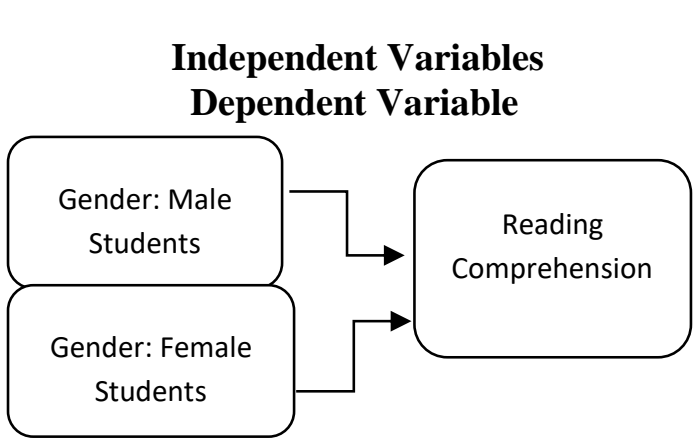

Figure 1. Relationship between Variables

Since it is difficult to form new groups randomly, the researchers decide to purposely choose two classes from the second grade, and then form two groups consisting of female and male students. The groups consist of 25 students each. The two groups will be given the same texts to read and later on answer comprehension questions developed based on the selected texts. Since the students involved in this study will not be randomly selected, the design used will be intact-group design. The design is displayed below.

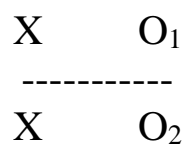

Note:

$\mathrm{X}=$ experimental treatment

$\mathrm{O}_{1} / \mathrm{O}_{2}=$ observation (or posttest)

\section{DATA ANALYSIS AND DISCUSSION}

The study is an experimental in nature using posttest-only control group design in which the two groups are exposed to 2 neutral texts and are tested using a 10 item multiple choice test afterward. Result of the testing is presented in Table 1.

Table 1. Posttest data of Male \& Female Groups

\begin{tabular}{|c|c|c|}
\hline No. & Female Group (X) & Male Group (Y) \\
\hline 1 & 8 & 7 \\
\hline 2 & 7 & 6 \\
\hline 3 & 6 & 6 \\
\hline 4 & 9 & 8 \\
\hline 5 & 7 & 6 \\
\hline 6 & 7 & 7 \\
\hline 7 & 7 & 5 \\
\hline 8 & 8 & 7 \\
\hline 9 & 8 & 6 \\
\hline 10 & 6 & 8 \\
\hline 11 & 7 & 7 \\
\hline 12 & 6 & 5 \\
\hline 13 & 7 & 7 \\
\hline 14 & 8 & 6 \\
\hline 15 & 7 & 7 \\
\hline 16 & 7 & 9 \\
\hline 17 & 8 & 7 \\
\hline 18 & 9 & 8 \\
\hline 19 & 7 & 6 \\
\hline 20 & 6 & 7 \\
\hline 21 & 7 & 6 \\
\hline 22 & 9 & 8 \\
\hline 23 & 7 & 6 \\
\hline 24 & 7 & 6 \\
\hline 25 & 6 & 7 \\
\hline 26 & 9 & 9 \\
\hline 27 & 7 & 6 \\
\hline 28 & 8 & 8 \\
\hline 29 & 7 & 7 \\
\hline 30 & 5 & 6 \\
\hline
\end{tabular}

As pointed out before, the data already collected are statistically analyzed using t-test for independent sample. For this purpose, it is necessary to firstly find out the sums and sum squares of $X$ and $Y$. 
Based on the calculation enclosed in Appendix 2, the followings are obtained.

Table 2. Sums and Sum squares of $X$ and $\mathrm{Y}$

\begin{tabular}{|l|l|}
\hline Female Group $(\mathrm{X})$ & Male Group $(\mathrm{Y})$ \\
\hline$\sum \mathrm{X}=230$ & $\sum \mathrm{Y}=210$ \\
\hline$\sum \mathrm{X} 2=1808$ & $\sum \mathrm{Y} 2=1512$ \\
\hline$\overline{\mathrm{X}}=8$ & $\bar{y}=7$ \\
\hline $\mathrm{N}=30$ & $\mathrm{~N}=30$ \\
\hline
\end{tabular}

Based on the results of computation of mean, sums and sum squares of $\mathrm{X}$ and $\mathrm{Y}$, statistical analysis using t-test for independent sample is manually carried out

$$
\begin{aligned}
& t_{(\text {observed })}=\frac{\mathbf{8}-7}{\frac{\sqrt{\left(\mathbf{1 8 0 8}-\frac{\mathbf{5 2 9 0 0}}{\mathbf{3 0}}\right)+\left(\mathbf{1 5 1 2}-\frac{\mathbf{4 4 1 0 0}}{\mathbf{3 0}}\right)}}{30+30-2} \cdot\left[\frac{1+\mathbf{1}}{30+30}\right]} \\
&= \frac{1}{\frac{1}{\sqrt{(1808-1763)+(1512-1470)}} \cdot \frac{2}{30}} \\
&=\frac{1}{\sqrt{\frac{45+42}{58} \cdot \frac{2}{30}}} \\
&=\frac{1}{\sqrt{\frac{87}{58} \cdot \frac{2}{30}}} \\
&=\frac{1}{\sqrt{1.5 \cdot 0.06}} \\
&=\frac{1}{\sqrt{0.09}} \\
&=\frac{1}{0.3} \\
& t_{(\text {observed })}=3.333
\end{aligned}
$$

Thus, $\mathrm{t}_{\text {(observed) }}$ is 3.333 , and at $p(\alpha) 0.05$ and $d f 58$, the $\mathrm{t}_{\text {(table) }}$ is 2.000 . Result of this statistical analysis is then compared or matched with the criteria for accepting or rejecting the null hypothesis displayed in Table 2.

\section{Table 3.Criteria for Accepting/Rejecting Ho.}

\begin{tabular}{|l|l|l|}
\hline Criteria & P level & Meaning \\
\hline
\end{tabular}

\begin{tabular}{|l|l|l|}
\hline $\mathrm{t}_{\text {(observed) }} \leq \mathrm{t}$ (table) & 0,05 & accept $\mathrm{H} \Theta$ \\
\hline $\mathrm{t}_{\text {(observed })} \geq \mathrm{t}_{\text {(table }}$ & 0,05 & Reject $\mathrm{H}_{\mathrm{o}}$ \\
\hline
\end{tabular}

Based on the criteria just mention, it can be said that the null hypothesis was rejected. This in other words, means that female students significantly outperformed their male counterpart.

The present study reveals that female students significantly outperformed their male counterpart in reading comprehension of neutral texts. This finding comes to support the previous research findings revealed by Oda and Abdul-Kadhim (2017), Anantasa (2016), Vlachos and Papadimitriou (2015), Keshavarz and Ashtarian (2008), Zhau (2008), and Wei (2009).

Oda and Abdul-Kadhim (2017), for example, finds that female students significantly outperformed their male counterparts in reading comprehension. Anantasa (2016) finds that girls perform better in reading comprehension than boys. Similarly, Vlachos and Papadimitriou' (2015) results show Gender is not found to play an important role in reading performance. Still in the same vein, Keshavarz and Ashtarian (2008) found that there is a difference between male and female EFL students in reading comprehension ability with females being better in the comprehension of English passages. Wei (2009) and Zhau (2008) reveal that a strong relationship existed between gender differences and reading comprehension that could affect test outcomes.

Other studies reveal that gender differences do not affect comprehension. Salehi et al (2014), for example, show gender differences do not have any significant effect on text comprehension. Asgarabadi, et al., (2015) that there is no statistically significant difference between 
male and female students' reading comprehension in these macro-genres. It is also shown that there is no significant difference observed between male and female learners in the overall use and employment of reading strategies in the descriptive and narrative macro-genres.

In contrast with the abovementioned findings, Al-Shumaimeri (2005) reveals that males performed significantly better in multiple-choice tests compared to their female counterparts, but no significant interaction effect is found between content familiarity and gender. Tae-Ilpae (2004) finds that items classified as mood/impression/tone tended to be easier for females, whereas items classified as Logical Inference are more likely to favor males regardless of item content. Similarly, Brantmeier's (2003) study leads her to conclude that her study shows that gender-oriented passage content and readers' gender are key variables that significantly affect their performance on the recall comprehension task at the intermediate level.

In conclusion, although more studies reveal that gender differences affect comprehension, more studies focusing on neutral texts are needed to make sure whether gender-differences affect reading comprehension.

\section{IV.CONCLUSION AND SUGGESTION}

\section{Conclusion}

Data Analysis indicates that at $p .05$ and $d f 58$, the t-observed is larger than $\mathrm{t}-$ table $[3.333 \geq 2.000)$. This indicates that female students outperformed their male counterparts in reading comprehension. In other words, it can be stated that gender differences affect reading comprehension.

\section{Suggestion}

The finding comes to support what experts and researchers that females are better in language learning, particularly reading, reveal. This finding is important for English teachers and EFL textbook writers, especially in choosing reading texts for their students and for inclusion in their textbooks. This finding suggests that it is important for them not to select reading texts that favor only female or male students. It is important for both English teachers and textbook writers to select neutral texts.

Some studies revealed that there is no significant effect of gender on comprehension. Therefore, more studies are needed to ensure the effect of gender differences on reading comprehension.

\section{REFERENCES}

Aghajani, Mojtaba.,Motahari, Masoud,. \&Qahraman, Vahid. 2013. The Effect of Text Familiarity and Reading Tasks on ESP Test Performances.Journal of Emerging Trends in Computing and Information Sciences, Vol. 4, No. 3.

Aina, A. J., Ogungbeni, J. I., Adigun, J. A. and Ogundipe, T. C. 2011.Poor Reading habits among Nigerian: the role of libraries. Library Philosophy and Practice (ejournal) Paper 529.Retrieved March 23, 2019 from http://digitalcommons.unl.edu/libp hilprac/529.

Ay, Sila\&Bartan, ÖzgürŞen. 2012. The Effect of Topic Interest and Gender on Reading Test Types in a Second 
Language. The Reading Matrix Volume 12, Number 1

Brantmeier, C. 2002. The effects of passage content on second language reading comprehension by gender across instruction levels. In $\mathrm{J}$. Hammadou Sullivan. (Ed.), Research in second language learning. Greenwich, CT: Information Age Publishing.

Brantmeier, C. 2003. Does gender make a difference? Passage content and comprehension in second language reading.Reading in a Foreign Language, 15(1), 1-23.

Davis, Glenn. 2016. Why is Reading Important? https://www.learn-toread-prince-george.com/why-isreading-important.html

Healy, Cathy. 2002. Reading: What the Experts Say. Parent Educational Advocacy Training Center. http://www.peatc.org/Fact\%20She ets/reading.pdf

Lietz, Petra. 2006. Issues in the change in gender differences in reading achievement in cross-national research studies since 1992: A meta-analytic view. International Education Journal, 7(2), 127-149.

Lynn, R., \&Mikk, J. 2009. Sex differences in reading achievement.Trames, 13 (63/58), 3-13.

Mullis, I. V.S., Martin, O.M., Gonzalez, E.J., \& Kennedy, M.A. 2003. PIRLS 2001 international report: IEA's study of reading literacy achievement in primary schools. Chestnut Hill, MA: Boston College. Retrieved May 26, 2008, from

http://pirls.bc.edu/pirls2001i/PIRL S2001_Pubs_IR.html

NorhizaBinti Ismail \&Fatin Nadia BintiFadzil.A Study on the Effects of Content and Gender in Text

Comprehension.Faculty of

Education, UniversitiTeknologi Malaysia.

https://core.ac.uk/download/pdf/11

786431.pdf

Oda, Ala H. \& Abdul-Kadhim (2018).The

Relationship between Gender and

Reading Comprehension at College

Level.Journal of BasrahResearch the Humanities sciences, Vol. 42, No. 6.

Oxford, R. L. 1994. La difference continue...: Gender differences in second/foreign language learning styles and strategies. In Sutherland, J. (Ed.), Exploring gender. (pp. 140-147). Englewood Cliffs, NJ: Prentice-Hall.

Pietil, Päivi.,\&Merikivi, Riika. 2014. The Impact of Free-time Reading on Foreign Language Vocabulary Development. Journal of Language Teaching and Research, Vol. 5, No. 1, pp. 28-36.

Saidi, AzhaarAmbu\& Al-Mahrooqi, Rahma. 2012. The Influence of Gender on Omani College Students' English Language Learning Strategies, Comprehension and Motivation. International Journal of Applied Linguistics and English Literature, Vol.1, No. 4.

Salehi, Mohammad.,Lari, Zahra., \&Rezanejad, Atefeh. 2014. The effects of gender and genre on language learners' reading comprehension ability. Education Journal, 3(5): 266-271.

Shahmohammad, Nayereh. 2011. The Effect of Gender-based Materials on Reading Comprehension. International Journal of Human Resource Studies, Vol 1, No. 2. 
Sotoudehnama, E \&Asadian, M. 2011. Effect of Gender-Oriented Content Familiarity and Test Type on Reading Comprehension. The Journal of Teaching Language Skills (JTLS) 3(2), Ser. 63/4.

UKEssays.2017. Definition of Reading. Retrieved from https://www.ukessays.com/essays/l anguages/definition-ofreading.php?vref $=1$

Vlachos, Filippos\& Papadimitriou. 2015. Effect of age and gender on children's reading performance: The possible neural underpinnings. Cogen Psychology, Volume 2, Issue 1.

Wong, J. J.8 Reasons Why Reading is so Important.

www.inspirationboost.com/8reasons-why-reading-is-soimportant

Yazdanpanah, Khatereh. 2007. The Effect of Background Knowledge and Reading Comprehension Test Items on Male and Female Performance. The Reading Matrix, Vol. 7, No. 2. 